\title{
Konglomerasi Media dan Partai Politik: Membaca Relasi MNC Group dengan Partai Perindo
}

\author{
Anggalih Bayu Muh. Khamim', Muhammad Fahmi Sabri2 \\ 1Departemen Politik dan Pemerintahan, Universitas Gadjah Mada \\ ${ }_{2}^{2}$ Departemen Politik dan Pemerintahan, Universitas Gadjah Mada
}

\begin{abstract}
Abstrak:
Konglomerasi media telah membawa Hary Tanoe mampu membuat Partai Perindo untuk memfasilitasi kepentingan politiknya. Artikel ini bertujuan untuk menggambarkan bagaimana strategi Perindo yang membangun hubungan dengan pemilih dengan dukungan sumber daya dari MNC Group. Untuk memenuhi tujuan tersebut, artikel ini ditulis dengan pengumpulan data yang dilakukan dengan menelusuri berbagai artikel jurnal, laporan penelitian serta liputan media daring mengenai Partai Perindo. Hasil penelitian menunjukan Hary Tanoe berusaha membesarkan Perindo dengan memanfaatkan pengerahan sumber daya MNG Group untuk mendukung partai dan meningkatkan citra dirinya. Keberhasilan Hary Tanoe sebagai pebisnis menjadi arahan bagi Perindo untuk mengerahkan berbagai bantuan UMKM untuk meraih dukungan dan kesetiaan dari pemilih. Perindo juga memberikan berbagai barang untuk memastikan bahwa pemilih benar-benar mendukung Perindo saat pemilihan. HT juga mengerahkan orang-orang terdekatnya di MNC Group untuk mensolidkan mesin partai dengan duduk di kantor pusat Perindo. Perindo juga memanfaatkan MNG Group untuk menayangkan berbagai iklan politik untuk mengenalkan partai pada pemilih secara masif.
\end{abstract}

Kata Kunci:

hubungan dengan pemilih; klientelisme; konglomerasi media; strategi Perindo

\section{Pendahuluan}

I

ndustri media massa Indonesia sulit melepaskan diri dari cengkraman politik dan ekonomi. Media massa kontemporer secara politik dan ekonomi telah menciptakan hegemoni, monopoli, kapitalisme lanjut, konglomerasi, kelompok dominan baru yang akan menjadi penguasa pasar publik, yang dapat dimanfaatkan untuk kepentingan kelompok tertentu untuk menyebarkan gagasangagasan politik secara lebih leluasa. Pemilik media telah berafiliasi dengan kelompok

Korespodensi:

Departemen Politik dan Pemerintahan, Fakultas IImu Sosial dan Ilmu Politik, Universitas Gadjah Mada. Jalan Sosio Yustisia No. 1, Bulaksumur, Yogyakarta 55281.

Email: anggalih.bayu@yahoo.co.id 
politik, sehingga dapat memberi peluang yang lebih terbuka untuk mentransformasikan gagasan politik tertentu untuk meraup suara publik dalam pemilu (Hasan, 2014).

Dominasi kepentingan para konglomerat dan relasinya dengan aparatur negara dan para aktivis partai membuat lebih dominan dalam menentukan wajah seperti apa ruang publik itu sendiri. Relasi antara masyarakat dan media tidak dapat dipisahkan karena media terlibat dalam proses penetapan nilai seperti kebebasan bicara, identitas, integritas, diversitas informasi yang akan dikonsumsi publik, sehingga media secara terorganisir dapat mendahulukan atau memenuhi kepentingan publik atau masyarakat luas. Dalam industri media, konsep kepentingan publik (public interest) ini mengisyaratkan, agar media memiliki sistem yang didasarkan pada keadilan, kejujuran, demokrasi, dan nilai-nilai sosial-budaya untuk menghindari keresahan dan kemarahan masyarakat (Pembayun, 2015).

Para pemilik media memanfaatkan usahanya untuk menunjukan citra politiknya. Pemilik media dapat dengan seenaknya mempengaruhi pembuatan berita, padahal media massa memiliki kekuatan didalam menggiring cara berpikir, persepsi, sikap dan perilaku masyarakatnya. Apa yang menjadi agenda media dengan berita-beritanya akan menjadi agenda pembicaraan masyarakat pula. Kondisi ini dalam kajian komunikasi massa dikenal dengan istilah agenda setting (Setiawan, 2010). Sementara itu, para jurnalis media yang owner-nya melakukan intervensi, mereka terkesan dibatasi ruang geraknya dan terpaksa mengikuti dengan peraturan, karena apabila mereka melawan top management, mungkin bisa terkena sanksi perusahaan, bahkan sampai pada tahap pemecatan (sanksi ekonomi) (Setiawan, 2010).

Berbagai riset berusaha menjelaskan bagaimana pemilik media memanfaatkan media miliknya untuk kepentingan politik. Riset yang dilakukan oleh Alfani (2014) menunjukan bahwa intervensi pemilik media telah membuat jurnalis terpaksa mengikuti kemauan pasar \& melayani pesanan elite politik. Industri media lebih berorientasi pada pemenuhan keinginan pasar sesuai dengan kriteria apa yang menguntungkan secara ekonomi dan politik bagi para pemilik modal (Alfani, 2014). Akibat dari monopoli kepemilikan media terhadap isi media pada dasarnya sulit untuk dibuktikan. Namun, monopoli dari pemilik media dikhawatirkan mampu mengancam kebebasan pers dan pilihan bagi konsumen. Akhirnya, jika pemilik selalu mengintervensi isi medianya untuk tujuan propaganda, maka akan muncul risiko media tersebut kehilangan peminat dan kredibilitasnya (Dwita, 2016). Media menempatkan audience semata-mata hanya dilihat sebagai pasar, bukan warga negara (citizens). Tujuan utama dari dibentuknya media adalah meraih keuntungan untuk pemilik dan para pemangku kepentingan lainnnya (Valerisha, 2016). Dengan demikian, fungsi media sebagai penyampai beragam gagasangagasan, informasi, pendidikan, dan integrasi sosial yang merupakan inti dari ketersediaan ruang publik, semakin terkesampingkan dengan kepentingan komersialisasi (Sucahya, 2013). Proses ini menunjukan adanya fenomena komodifikasi media. 
Hasil penelitian yang dilakukan oleh Yulianti (2015) terhadap Media Indonesia milik Surya Paloh menunjukan bahwa komodifikasi media telah memfasilitasi kepentingan politik pemilik media sekaligus bisnis secara bersamaan. Komodifikasi media telah mendorong pemilik media untuk melakukan integrasi usaha, mengintervensi jurnalis dan konten pemberitaan, menyeleksi iklan yang menyebabkan kompetensi pekerja kurang diperhatikan dan semata digunakan sebagai alat produksi (Yulianti, 2017). Proses agenda setting dan framing yang dilakukan oleh media disesuaikan dengan kepentingan pemiliknya. Kebenaran yang tidak didapatkan masyarakat tersebut dapat menyebabkan masyarakat terhegemoni dengan menerima kebenaran versi media massa. Kepemilikan oleh sekelompok tertentu juga berakibat pada terjadinya homogenisasi informasi. Pemilik media pun memanfaatkan berbagai iklan untuk membiayai kepentingan politik dan orientasi diri (Habsari, 2012).

Riset yang dilakukan oleh Ardiyan \& Sulandjari (2017) di salah satu desa Kabupaten Semarang menemukan bahwa strategi iklan politik dan pemberitaan yang diintervensi oleh pemilik media yang juga elite politik ternyata belum tentu berpengaruh terhadap opini publik disebabkan masyarakat hanya melihat media sebagai sumber hiburan semata. Sayangnya riset ini, dilakukan dalam scope yang kurang memadai secara makro pengaruh intervensi tayangan pada citra politik pemilik media (Ardiyan and Sulandjari, 2017). Akan tetapi, usaha eksploitasi media oleh para pemiliknya terus menguat. Jika dilihat duduk perkaranya, maka eksploitasi media telah terjadi, karena seringkali niat sadar yang dilakukan pejabat atau perusahaan itu hanya memberikan otorisasi atau intervensi yang sengaja dimasukan ke dalam sebuah media massa, proses komunikasi tersebut membuktikan jelas bahwa bias politik serta kepentingan golongan telah terjadi (Rahman et al., 2018).

Dari berbagai tokoh yang telah menjadi pemilik media sekaligus elit politik, Hary Tanoesodibjo (HT) menjadi tokoh yang paling menarik untuk diteliti. Pertama, apabila diuraikan, Hary Tanoesodibjo memiliki kerajaan media terbesar se-Asia Tenggara. Perusahaan media taipan asal Surabaya ini meliputi PT Media Nusantara Citra Tbk, PT Global Mediacom Tbk, PT MNG Sky Vision, RGTI, AnTV, Viva News, dan Global TV. Kedua, karier politik HT yang relatif baru termasuk dengan pendirian Partai Perindo relatif menarik digali, meskipun sebelumnya HT pernah masuk menjadi kader Partai Nasdem dan Partai Hanura (Rosalia, 2014). Namun, sikap militan pemanfaatan media dan strategi klientelistik yang dimanfaatkan HT sebagai konglomerat media untuk membesarkan partainya menjadi hal yang menarik untuk digali sekaligus didalami dalam rangka mengevaluasi proses demokratisasi di Indonesia yang diwarnai dengan sikap paternalistik.

Pemanfaatan media oleh HT memang cukup beralasan disebabkan media dan politik memiliki hubungan yang resiprokal. Politik memerlukan publikasi untuk mendiseminasikan ideologinya kepada publik secara meluas dan media memerlukan fgur politisi untuk mendongkrak citra komersialisasi media di ranah publik (Jati, 2013). 
Kondisi ini dimanfaatkan oleh elite politik untuk berafiliasi dengan media. Media menjadi menunjukan keberpihakan dan dukungan politiknya pada pemiliknya (Bahruddin, 2014). Elite politik yang dekat dengan pemilik media pun menjadi dapat memanfaatkannya untuk menunjukan citra politiknya. HT sendiri sebelum mendirikan Partai Perindo diperhitungkan untuk bergabung dengan partai politik disebabkan oleh konglomerasi medianya dan kemampuan finansialnya untuk dijadikan instrumen politik (Rosalia, 2014).

HT dan para pengurus Partai Perindo yang juga memanfaatkan media MNG Group untuk membangun hubungan dengan calon pemilih. HT sendiri memanfaatkan MNC Group beserta para pekerjanya untuk menjadikannya sebagai media partisan untuk membesarkan Partai Perindo. Riset yang dilakukan oleh Hariyadi (2018) menunjukan bahwa MNG Group berubah tidak hanya berorientasi profit oriented, tetapi juga instrumen bagi Partai Perindo untuk mensosialisasikan diri pada calon pemilih. Akan tetapi, penelitian ini kurang mendalam dalam memahami keterkaitan antara konglomerasi MNC Group dan Partai Perindo dalam usaha yang dilakukan HT untuk menyusun berbagai strategi mendekati pemilih (Hariyadi, 2018).

Pendalaman berbagai strategi yang digunakan HT untuk membesarkan partainya dengan memanfaatkan konglomerasi medianya perlu didalami lebih lanjut. Kajian ini akan memaparkan strategi HT untuk memanfaatkan MNC Group untuk membangun kedekatan antara Partai Perindo dengan konstituen. Pengkajian terhadap strategi yang digunakan HT untuk membangun hubungan dengan pemilih perlu dilakukan untuk memastikan bahwa partai politik dalam berorganisasi tidak semata bergantung pada konglomerasi media. Sulitnya memisahkan Partai Perindo dengan MNG Group menyebabkan beragam bias-bias yang mencerminkan seolah-olah partai politik dan media semata menjadi milik privat. Apabila ketergantungan Partai Perindo pada MNG Group tidak segera dievaluasi akan menyebabkan hubungan yang dibangun dengan konstituen semata untuk melayani kepentingan elite, sehingga isu publik kurang didengarkan.

\section{Clientelistic Linkage: Sebuah Kaca Mata Teoritik}

Riset ini dibingkai dengan memakai kerangka teoretik clientelistic linkage untuk melihat hubungan antara parpol, konglomerasi media dan konstituen. Dari sudut pandang pemilih, partai yang memanfaatkan tautan politik klientelistik dan programatik berbeda dalam hal bagaimana berbagai logistik diberikan kepada pemilih sebagai bentuk ikatan pertukaran. Di dalam ikatan programatik, pemilih mengharapkan adanya panduan program parpol/kandidat, perencanaan sektor publik, dan program umum akan disampaikan melalui kader partai di akar rumput. Dalam kasus lain, pemilih akan membangun hubungan dengan parpol maupun kandidat melalui pemberian barang/pelayanan melalui skema kebijakan publik untuk menunjukan bahwa partai melaksanakan janji politik (Calvo and Murillo, 2013). 
Partai politik juga menyediakan sebuah portofolio barang publik yang mungkin tidak dapat dijanjikan untuk diberikan kepada para pemilih. Mekanisme penentuan akses ke barang yang tidak ada atau belum bisa diwujudkan dalam program partai dilakukan melalui beberapa kriteria kebijakan umum atau melalui pemaparan oleh jaringan kader di akar rumput untuk membentuk pemahaman pemilih mengenai kebijakan apa yang menjadi prioritas untuk segera dilaksanakan. Pemilih perlu menentukan sendiri aspirasi mengenai isu publik apa yang harus segera diselesaikan partai, kemudian mereka harus memutuskan dukungan untuk menentukan memberikan suaranya atau tidak (Calvo and Murillo, 2013).

Sebaliknya, klientelisme melibatkan timbal balik dan kesukarelaan, tetapi juga eksploitasi dan dominasi. Logika pertukaran asimetris terjadi dengan adanya transaksi antara pemiih dengan partai/kandidat secara terbuka. Pihak-pihak klientelis sering dapat menangani kompleksitas sumber daya material yang akan mengalir melalui investasi besar dalam infrastruktur partai berupa administrasi serta mesin politik yang bertingkat mulai dari kantor pusat di tingkat nasional sampai ke akar rumput. Klientelisme mungkin hampir sama dengan kepemimpinan kharismatik seperti yang dicirikan dengan baik oleh Weber (1978) sebagai bagian dari langkah programatik secara terselubung (Kitschelt, 2000).

Clientelistic linkage melibatkan politisi untuk menyuplai pemilih yang ditargetkan melalui pemberian club goods skala kecil untuk individu dan kelompok warga. Proses pertukaran sosial itu dapat memperpanjang putaran kompetisi elektoral yang berulang dan memberikan dukungan politik mereka kepada parpol maupun kandidat dalam pemilihan. Transaksi itu mungkin hanya satu kali, tetapi harus tekankan bahwa ikatan antara pemilih dengan kandidat/parpol cukup sering bertahan selama periode waktu yang lebih lama, termasuk beberapa pemilihan (Kitschelt, 2011).

Politisi dapat menawarkan barang yang ditargetkan sebelum atau sesudahnya setiap kontes elektoral atau sepanjang masa politik antara pemilihan. Seringkali, sulit untuk mengatakan apakah hubungan politisi dengan broker terutama berdasarkan pembelian suara langsung dalam arti sempit atau ditandai dengan waktu spesifik dari pemberian barang/uang menjelang pemungutan suara. Hubungan klientelistik dapat mencakup proses pertukatan sosial sering dibantu dan dimediasi oleh lapisan "broker" yang mengatur dan mengelola hubungan klien (Kitschelt, 2011).

Penggunaan broker dapat memberikan manfaat jangka panjang dan abadi kepada parpol/kandidat melalui pemberian pada kelompok tertentu melalui skema kebijakan publik, seperti akses ke fasilitas kesehatan, pekerjaan di lembaga publik/nirlaba, atau sektor swasta yang diatur dan disubsidi. Skema dukungan melalui pengaturan pendapatan pada kelompok tertentu yang memerlukan kualifikasi individual untuk menerima manfaat sesuai dengan kriteria kompleks dan membuat penghargaan pada pemilih tidak pasti, seperti dalam kasus kebijakan dana pensiun, beasiswa pendidikan, atau perumahan bersubsidi dan kemungkinan akan dicairkan menurut logika 
pertukaran klientelis dengan politisi terpilih (Kitschelt, 2015). Broker adalah pialang yang merekayasa pergerakan barang dan jasa yang merupakan imbalan dukungan klien. Broker akan melakukan pemantauan dan sanksi pada calon pemilih yang telah menerima pemberian tertentu untuk memastikan bahwa kandidat/parpol benar-benar dipilih pada setiap pemilihan (Kitschelt, 2011).

Kondisi lain dapat terjadi tanpa melalui broker di mana parpol ataupun politisi memanfaatkan personalisasi politiknya untuk memenangkan pemilu. Keadaan seperti ini dapat terjadi kala pemimpin partai benar-benar memiliki ambisi untuk memenangkan kekuasaan dengan mengerahkan sumber daya yang dimilikinya, mempersonalisasi kantor pusat partai dan memanfaatkan kharisma pribadinya. Mereka mempersonalisasikan persaingan untuk meraih jabatan tertinggi dan menarik politisi ambisius sebagai mesin politik (Kitschelt, 2000).

Mereka digerakkan melalui jaringan dukungan pribadi yang ditopang oleh kharisma dan kroni, bukan oleh program kebijakan. Kontestasi melalui personalisasi kantor publik mendorong para kandidat untuk melemahkan program dan menerbitkan janji-janji politik serta kharisma yang dapat menarik pemilih. Hal ini membuatnya mudah bagi mereka untuk dipilih dan mempertahankan hubungan klientelistik yang saling melengkapi (Kitschelt, 2000). Kondisi ini terjadi secara riil seperti dalam pemenangan partai Forza Italia yang dibidani oleh Silvio Berlusconi.

Masuknya Berlusconi dan perusahaannya, Fininvest, di arena politik berarti masuknya swasta, kepentingan pribadi secara resmi menunjukan pemanfaatan sumber daya usaha untuk memenangkan pemilu. Berlusconi mengkonfigurasikan pemenangan Forza Italia melalui dukungan kharisma pribadinya dan kerajaan bisnis medianya. Kemenangan Forza Italia pada pemilu tahun 1994 telah membuat Berlusconi mengubah dirinya dari wirausahawan media menjadi Perdana Menteri Italia. Karakteristik penting Forza Italia adalah konfigurasinya sebagai organisasi patrimonial yang dimiliki dan diarahkan secara otokratis oleh pendirinya dan pemimpinnya. Karakteristik partai ini terkait erat dengan karakter partai perusahaan bisnis, di mana "ideologi" Finivest juga dieratkan dengan pengelolaan dan pemenangan Forza Italia. Kepemimpinan kharismatik memainkan fungsi legitimasi penting dengan membenarkan patrimonialisme secara internal dan model partai perusahaan bisnis secara eksternal. Pola hubungan seperti ini dilakukan Forza Italia untuk menjaga kesetiaan para kader partai dan dukungan pemilih (Mancini, 2011).

Berlusconi memanfaatkan kondisi politik yang dipengaruhi serta kebutuhan para politisi untuk memanfaatkan dan menguasai media sebagai jalan baginya untuk masuk ke arena kekuasaan. Berlusconi terjun ke dunia politik dibiayai melalui kerajaan medianya dan dipromosikan secara masif oleh para eksekutif dari agensi periklanannya, Pubblitalia. Perusahaan media Finivest diinstruksikan untuk mendukung kepentingan politiknya. Gaya politik baru ini terjadi disebabkan sebagian partai politik mana pun di dunia demokrasi kehilangan anggota dan kekuasaan, sehingga membuat politisi semakin 
beralih ke media massa untuk menyampaikan pesan mereka. Warga semakin diperlakukan sebagai audiens serta pemilih semata (Paolucci, 2006).

Kekuatan Berlusconi tidak hanya terletak pada kekayaan dan pengaruh medianya, tetapi juga dalam nilai-nilai yang dipromosikannya. Finivest menyiarkan berbagai pemberitaan, acara tv serta hiburan yang telah memberikan dukungan kuat kepada Berlusconi. Meskipun, Berlusconi adalah contoh luar biasa dari politisi sebagai manipulator media, tetapi ia tidak boleh dilihat sebagai satu-satunya pengecualian. Kemudian, strategi Berlusconi ditiru oleh Presiden Prancis, Nicolas Sarkozy dalam upaya memenangkan pemilu. Tren memanfaatkan kerajaan media, personalisasi politik sebagai bagian dari strategi klientelistik disebabkan oleh runtuhnya narasi besar oleh partai-partai politik pada abad ke-19 dan ke-20 yang membawa perjuangan berbasis kelas sosial terutama di Eropa (Paolucci, 2006).

Kasus sama pemanfaatan personalisasi politik dan kerajaan media dalam arena politik di Indonesia ditandai dengan kehadiran Partai Perindo besutan Hary Tanoe. Perindo muncuk untuk memfasilitasi ambisi kekuasaan dari pendiri dan pemimpinnya. Perindo muncul menjadi satu-satunya perwujudan model partai perusahaan bisnis di Indonesia dan menandakan perubahan dalam pengembangan demokratisasi. Meskipun, Perindo sebagai partai politik baru belum teruji dalam pemilihan, setidaknya memberikan suasana politik baru. Perindo menjadi fenomena tersendiri dengan menghadirkan wadah baru di luar kalangan elite lama setelah masa Reformasi Tahun 1998 melalui sokongan kerajaan media milik HT (Rohman and Afala, 2017).

Beberapa riset mencoba memahami usaha HT dan Perindo sebagai partai baru dalam upaya meraih suara dari para pemilih. Kebanyakan riset yang ada melihat strategi yang dilakukan oleh HT sebagai wujud marketing politik dan konsolidasi internal. Usaha Perindo untuk membangun dukungan dari pemilih melalui berbagai bantuan UMKM, pelayanan sosial, dan lain-lain dapat dilihat sebagai usaha HT dan jajarannya untuk mem-branding partainya sebagai parpol yang mengedepankan perbaikan kesejahteraan sosial (Hastomo and Aras, 2017; Rahmah and Maimun, 2018). Berbagai riset yang ada melihat Perindo mungkin berhasil dalam melaksanakan program sesuai platform partai, tetapi akibat dari kader yang kurang berhasil dalam memetakan segmentasi pemilih.

Riset-riset lain melihat upaya Perindo mengenalkan dirinya sebagai partai baru lewat iklan politik dan mars partai di media milik HT (Giovanni, 2016; Kosasih, 2016; Ariviyanti and Nurfebiaraning, 2017; Khumairoh and Aida, 2018). Penguatan figur HT yang menjalankan berbagai bantuan UMKM Perindo berusaha ditekankan sebagai substansi utama (Haq, 2017; Salsabila, 2017). Riset menunjukan iklan politik dan mars partai Perindo di media milik HT mampu mensosialisasikan program kepada pemilih pemula (Zeke, 2014; Noor, 2017; Ochtiva, 2017; Andarwati, 2018). Akan tetapi, risetriset itu sayangnya belum mampu melihat keterkaitan antara strategi bantuan-bantuan Perindo dengan iklan politik di media milik HT sebagai keseluruhan strategi yang saling terkait untuk mendekati pemilih. Kajian ini akan berusaha memahami lebih jauh strategi 
yang digunakan HT untuk memanfaatkan kerajaan medianya dan kharismanya untuk mendekatkan Perindo pada calon pemilih.

Untuk mencari jawaban dari berbagai latar belakang di atas, maka penulis menggunakan penelitian kualitatif tipe penelitian deskriptif sebagai metode penelitian. Metode ini dipilih untuk menggambarkan strategi-strategi yang digunakan oleh Partai Perindo dengan memanfaatkan pengaruh Hary Tanoesoedibjo dalam grup media yang dipimpinnya untuk membangun relasi dengan calon pemilih. Pengumpulan data dilakukan dengan teknik dokumentasi dengan melakukan penelusuran terhadap berita terkait program Partai Perindo melalui media online, penelusuran terhadap dokumendokumen Partai Perindo dan laporan penelitian serta artikel jurnal ilmiah yang terkait dengan strategi yang digunakan oleh Partai Perindo untuk mencari dukungan. Analisis data dilakukan melalui tahapan reduksi data, penyajian data, verifikasi dan penarikan kesimpulan.

\section{Hary Tanoe, MNG Group, dan Kepentingan Politiknya}

Posisi HT sebagai politisi pebisnis sekaligus pemimpin MNG Group dan Perindo telah mendorong hadirnya fenomena oligarki sipil yang muncul. Keberadaan HT yang sudah berpengaruh semenjak awal reformasi lewat kedekatannya dengan Bambang Trihatmojo (Putra Presiden Soeharto) dapat dikatakan modal awal yang akan menaikkan karier politik HT. Hary memang dekat dengan keluarga Cendana saat ia bekerja di bawah perusahaan Bambang Trihatmodjo, PT Bimantara Citra. Sejak saat itu, kariernya menanjak ketika kepemilikan sahamnya mencapai 40 persen dan diangkat sebagai Direktur Umum PT Bimantara Citra.

Sebelum terjun masuk partai pun, keberhasilan HT di dunia bisnis media telah menaikkan posisi politiknya ketika menghadapi "sengketa" dengan Keluarga Cendana. Bambang Trihatmodjo resmi mengundurkan diri sebagai Komisaris BMTR terhitung sejak RUPS Global Mediacom pada 30 April 2012. Seluruh perusahaan yang dulunya dikuasai keluarga Cendana ini diambil alih oleh Hary Tanoe. HT juga menghadapi kisruh kepemilikan di MNCTV yang dulunya bernama TPI dengan Siti Hardianti Rukmana alias Tutut, salah satu putri almarhum Soeharto (Detik.com, 2012).

Secara terbuka, HT pernah mengungkap sengketa bisnisnya dengan Mbak Tutut dalam kepemilikan televisi TPI. Dalam sengketanya, Mbak Tutut merespon Hary Tanoe dengan antara lain menempatkan tokoh Pemuda Pancasila, Japto Suryosumarno. Ditampilkannya Japto oleh Mbak Tutut diperkirakan untuk memberikan semacam kesan bahwa Hary Tanoe harus lebih berhati-hati atau dia perlu siap berhadapan dengan Mbak Tutut dalam cara apapun. Namun, Hary Tanoe tidak memperlihatkan rasa gentarnya (Fernando, 2012).

Sengketa Mbak Tutut dan Hary Tanoe secara formal dimenangkan oleh Mbak Tutut. Namun realitasnya saat itu, Mbak Tutut tidak bisa mengontrol TPI. Bahkan, TPI secara de facto sudah tidak lagi bersiaran. Hary Tanoe tidak puas, apabila tidak memperlihatkan kecerdikannya atas Mbak Tutut. Ketika Mbak Tutut belum siap 
mengelola TPI, Hary Tanoe tiba-tiba meluncurkan stasiun TV baru dengan nama MNC TV. Kalangan dunia broadcasting melihat bahwa MNC TV adalah nama lain dari TPI. Penggunaan nama dan logo baru ini cukup mengejutkan. Sebab, dalam peluncurannya tak terhalang sama sekali oleh berbagai aturan birokrasi, termasuk Komisi Penyiaran Indonesia (KPI) tidak bersuara (Fernando, 2012).

Posisi politik HT yang kuat sebelum masuk dan mendirikan partai juga terlihat ketika HT menggunakan media yang dimilikinya untuk memberitakan masalah sengketa bisnis yang sedang menjeratnya dengan Keluarga Cendana hanya diumumkan dan heboh di media grup MNC saja. Apabila, diberitakan di grup media yang lain isinya tidak terlalu membela HT. Pengumuman dari kuasa hukum grup MNC dalam kasus tersebut secara resmi hanya tampil di koran Sindo. Padahal, secara oplah Kompas masih jadi yang terbesar dan biasanya jadi salah satu surat kabar yang cocok untuk mengumumkan putusan atas beragam kasus di pengadilan. Hal ini telah membuat sebagian pihak ragu akan keseriusan grup MNG memperkarakan kasus-kasus tadi (Fernando, 2012).

Sejak berkiprah di PT Bimantara, Hary Tanoe pun mulai tertarik dengan dunia media saat melihat RCTI. Hary banyak menjual saham dan usahanya, namun ia mempertahankan RCTI. Seiring perkembangan bisnisnya, Hary Tanoe pun mulai mentransformasikan bisnis PT Bimantara Citra yang bersifat konglomerasi diubahnya menjadi perusahaan media. PT Bimantara Citra diubah menjadi PT Global Mediacom dengan menjual usaha yang tidak berkaitan dengan media pada tahun 2007 (Wahono, 2013).

Fenomena keberhasilan grup media yang dikelola oleh HT yang ikut menaikkan posisi politiknya menunjukan bagaimana pengaruh konglomerasi media benar-benar telah mendorong peningkatan bargaining position dan memunculkan corak klientelistik yang muncul. Fenomena HT dan kerajaan bisnis medianya dapat dijelaskan melalui temuan dari Daniel C. Hallin dan Stylianos Papathanassopoulos (2000) mengenai konglomerasi media yang memunculkan demokrasi yang bercorak klientelistik di Eropa Selatan dan Amerika Latin.

Tren ini juga muncul untuk menjelaskan fenomena HT dan langkah politiknya. Konglomerasi media memang terkait dengan corak klientelistik. Klientelisme telah menjadi karakteristik yang muncul pada tatanan sosial yang telah mengalami berbagai komodifikasi. Klientelisme telah berkembang di media yang telah dikomersialkan. Ketika pemilik media mendapat untung dengan menjual publisitas untuk politisi, atau ketika industrialis menggunakan wartawan untuk membangun citra positif politisi, maka akan mendukung kegiatan bisnis mereka yang lain. Hal ini menunjukan bahwa ubungan klien jelas melayani tujuan komersial (Hallin and Papathanassopoulos, 2000).

Pada tahun 2011, Hary Tanoesoedibjo memulai sebuah kegiatan baru yang tidak berasal dari bidang usaha. Sebelum mendirikan partai sendiri, Hary Tanoesoedibjo juga terlibat dalam dunia politik. Tercatat dua partai seperti Nasdem dan Hanura merupakan partai yang pernah menjadikan Hary Tanoesodibjo sebagai pengurus, meskipun tidak 
lama. Akhirnya, Hary Tanoesoedibjo keluar dan kemudian mendirikan partai Perindo pada tahun 2015. Meskipun memiliki pengalaman di partai politik, Hary Tanoesoedibjo belum mendapat pengalaman matang untuk memimpin sebuah organisasi politik secara berkelanjutan. Hal tersebut menjadi kelemahan yang dimiliki oleh Hary Tanoesoedibjo, karena Partai Perindo yang didirikannya merupakan partai baru (Sitanggang and Dharmawan, 2016).

Perindo didirikan oleh Bos MNG Group Hary Tanoesoedibjo pada 7 Februari 2015 di JIExpo, Kemayoran, Jakarta. Awalnya, Perindo berbentuk organisasi kemasyarakatan (ormas) yang dibentuk pada 24 Februari 2013. Deklarasi Perindo turut dihadiri para petinggi Koalisi Merah Putih seperti Ketua Umum Golkar Aburizal Bakrie, Presiden PKS Anis Matta, dan Ketua Umum PAN Hatta Rajasa (Manado.Tribunnews.com, 2018). HT telah memiliki modalitas yang kuat lewat grup medianya, sehingga memiliki posisi yang kuat baik di internal Perindo maupun kelompok politik lain. Manuver yang sering dibuat oleh HT mulai dari ketika bergabung Nasdem, Hanura sampai ketika mendirikan Perindo dan sempat mendukung koalisi PrabowoHatta sampai mampu mempengaruhi arah partai Perindo untuk mendukung pemerintahan Jokowi-JK menunjukan posisi politiknya yang kuat.

HT telah memperlihatkan dirinya sebagai bagian oligarki sipil yang muncul pascareformasi. Setelah, Soeharto turun dari jabatan presiden, banyak bermunculan oligarki baru yang tersebar dalam semua lini bidang politik termasuk politisi bisnis seperti HT. Dalam suatu oligarki sipil, tidak semua orang kaya adalah oligark. Oligark adalah mereka yang cukup kaya untuk mengubah uang mereka menjadi kekuatan profesional yang dibutuhkan untuk mempertahankan kekayaan dan harta. Pentingnya penentuan syarat oligark terletak pada kapasitas kekuasaan yang didapat individu- individu tertentu dari kekayaan pribadi mereka. Walaupun, kekuasaan mobilisasi bisa mengubah suatu kelompok atau masyarakat, salah satu kelemahannya adalah bahwa pelaku yang memobilisasi dan kekuatan sosial yang termobilisasi harus menginvestasikan waktu dan upaya pribadi cukup banyak untuk membangun sumber daya kekuasaan tersebut. Hal ini menyebabkan mobilisasi sukar dipertahankan (Winters, 2011).

Keterlekatan antara bisnis HT dan Partai Perindo menyebabkan jaringan patronase menjadi kunci penggerak partai. Rekrutmen kader Partai Perindo dalam beberapa hal sebenarnya dilakukan secara "tertutup." Pengisian jabatan di dalam partai dilakukan dengan melihat pertimbangan khusus seperti hubungan keluarga, kerabat, status sebagai pengusaha, ataupun kesamaan identitas kesukuan. Proses rektutmen yang terjadi dalam internal Perindo juga dilandasi berdasarkan kekecewaan para kader terhadap keanggotaan di partai sebelumnya (Sylvany, 2018). Jaringan patronase ini menjadi hal yang berpengaruh dalam pengisian jabatan di Partai Perindo baik di kantor pusat maupun cabang.

HT sengaja menjadikan orang-orang terdekatnya untuk menjadi penggerak infrastruktur partai. Para pejabat di internal perusahaan MNG Group menjadi penggerak 
utama di kantor pusat partai untuk memengaruhi arah gerak sampai kantor cabang. 14 orang pejabat perusahaan MNC Group menjadi bagian dari 33 orang yang menjadi pengurus Dewan Pimpinan Pusat Partai Perindo. Hal ini juga diikuti dengan pengurus majelis persatuan partai dan mahkamah partai yang juga didominasi oleh orang-orang dekat HT. Jaringan patronase sengaja digerakkan HT untuk memastikan bahwa strategi partai untuk membangun kedekatan dengan calon pemilih. Jaringan patronase juga dapat memastikan soliditas partai khususnya di kantor pusat (Kresna, 2018). Jaringan patronase yang dimiliki Perindo juga akan membantu partai dalam melakukan berbagai strategi untuk meraup suara dari pemilih di akar rumput. Infrastruktur partai akan mengerahkan semua sumber daya yang dimilikinya untuk memenangkan kontestasi pada masa pemilihan umum.

\section{MNG Group dan Perindo: Pola Meraih Konstituen}

HT mengarahkan Perindo untuk menjadikan bantuan UMKM sebagai strategi partai dalam membangun kedekatan dengan pemilih. Kader partai Perindo mengikuti segala arahan HT untuk memanfaatkan bantuan UMKM, demi memastikan terpilihnya Perindo pada masa pemilihan umum. Sosok HT cukup disegani oleh kader-kader Perindo, sehingga kesuksesannya di dunia bisnis oleh para kader dijadikan sebagai semangat partai untuk membawa perubahan lewat jiwa kewirausahaan. Atas arahan pemimpinnya, Perindo memberikan banyak bantuan UMKM kepada calon konstituennya berupa pemberian gerobak usaha, pelatihan keterampilan, pinjaman usaha, dan lain-lain (Atmaja, 2017).

Strategi klientelistik yang digunakan oleh Perindo berbeda dengan klientelisme pada umumnya, karena tidak memanfaatkan sumber daya yang dimiliki Negara. Posisi Perindo yang masih di luar pemerintahan belum memungkinkan Perindo untuk memanfaatkan sumber daya negara. Perindo masih bergantung pada media milik HT untuk mengenalkan bantuan UMKM Partai Perindo, sehingga klientelisme yang muncul dibiayai melalui pembiayaan swasta (Hastomo dan Aras, 2017). Posisi HT sebagai politisi pebisnis juga kebanyakan pengurus di tingkat kantor pusat maupun kantor cabang yang berasal dari kalangan pengusaha menunjukan ketergantungan partai terhadap sumber daya privat (Gherghina and Volintiru, 2017).

Strategi klientelistik berupa bantuan UMKM yang digunakan Perindo lewat pendanaan swasta juga telah mengurangi peran broker (Gherghina and Volintiru, 2017). Partai Perindo dengan kader-kadernya justru langsung menjadi penyalur dari bantuan UMKM yang diberikan oleh partai. Partai Perindo langsung menyalurkan bantuan UMKM kepada kelompok pemilih tertentu yang dituju dengan fokus pada komunitasnya baik nelayan, petani maupun pedagang kecil. Perindo menghilangkan peran broker dalam menjaga kesetiaan pemilih pula dengan memastikan bahwa bantuan UMKM yang diberikan tidak dialihkan pemiliknya dengan melakukan pengecekan langsung oleh kader partai. 
Strategi klientelistik yang digunakan oleh Perindo juga berimplikasi pada munculnya "pertukaran" antara partai yang memberikan bantuan UMKM dengan kelompok pemilih penerima bantuan (Szwarcberg, 2013). Hal ini telah mendorong munculnya "kompromi politik" antara partai dengan calon pemilih dalam membangun relasi (Walle, 2007). Perindo memberikan kewajiban yang harus dipenuhi oleh pihakpihak yang menerima bantuan UMKM khususnya bagi yang berupa pemberian gerobak. Berdasarkan yang tertera dalam surat komitmen mitra binaan UMKM partai Perindo konsekuensi yang muncul dari pemberian bantuan adalah sebagai berikut:

Pertama, Perindo melarang bantuan gerobak yang digunakan untuk berjualan di tempat yang dilarang oleh pemerintah. Apabila hal tersebut dilakukan, maka Perindo akan menarik kembali bantuan yang telah diberikan. Kedua, tempat berjualan tidak digunakan untuk tempat perjudian, penjualan miras dan narkoba. Perindo akan menarik kembali bantuan yang telah diberikan bila penerima melanggar kesepakatan tersebut. Ketiga, penerima dilarang mencabut atribut yang tertera dalam bantuan UMKM yang diberikan, dimana bila dilanggar Perindo akan menarik kembali bantuan yang telah diberikan. Keempat, Perindo juga melarang penerima mengalihkan kepemilikan bantuan usaha yang telah diberikan, dan apabila dilanggar penerima harus melakukan ganti rugi kepada partai senilai bantuan yang diberikan. Terakhir, penerima juga wajib menjadi anggota partai Perindo, mitra UMKM binaan Partai Perindo dan anggota Koperasi Partai Perindo setelah menerima bantuan.

Perindo juga melakukan berbagai pemberian sebagai wujud pertukaran sosial di berbagai bidang lain untuk membangun kedekatan dengan pemilih. Di bidang sosial, Perindo memberikan pelayanan ambulans gratis dan fogging. Di bidang pertanian, Perindo memberikan bantuan alat pertanian dan bibit berkualitas. Perindo juga sering mengadakan berbagai kegiatan olahraga seperti turnamen sepak bola, futsal, maupun lomba binaraga serta pendidikan politik bagi pemilih pemula. Perindo melalui kaderkader dan kantor cabangnya juga mengadakan berbagai program reaktif dan insidental seperti pembagian sembako, pengobatan gratis, dan rumah inspirasi. Semua bentuk pemberian kepada calon pemilih diberikan mengikuti dengan kelompok sosial yang disasar. Perindo di tingkat kantor cabang juga melakukan berbagai program mengikuti kemampuan finansial politisi. Perindo sengaja mengedepankan pemberian barang tertentu pada kelompok pemilih yang disasar untuk memobilisasi dukungan mereka di masa pemilihan umum. Perindo berusaha membangun kesetiaan sekaligus mengenalkan partainya dengan berusaha "merespon kebutuhan" warga.

HT memanfaatkan grup media miliknya untuk mengenalkan pada publik berbagai program bantuan UMKM yang diusung oleh Perindo. HT tidak main-main untuk mengerahkan media yang dimilikinya dalam melakukan sosialisasi Partai Perindo melalui iklan politik. Perindo ditampilkan melalui iklan politik dan pemutaran mars partai yang menggambarkan sikap parpol terhadap kemajemukan Indonesia dan berbagai program kerja yang diusung (Mulyadi, 2016). Secara keseluruhan, opini terhadap iklan 
politik Perindo yang ditampilkan dalam media milik HT menunjukan respon positif dari calon pemilih. Penampilan iklan politik Perindo di media milik HT sukses dalam mengenalkan program kerja dan capaian kinerja partai. Konten-konten yang berusaha ditampilkan dalam iklan politik yang dilakukan lewat media-media milik HT mendapat apresiasi positif terutama dari kelompok pemilih pemula (Ochtiva, 2017).

Media HT menampilkan iklan politik Perindo lewat dua metode yang berbeda. Perindo disiarkan melalui televisi dan radio melalui pemutaran mars partai secara terus menerus. Sementara, untuk informasi kegiatan dari program-program Partai Perindo dibalut dengan konsep pemberitaan. Sejumlah persoalan sempat dialami oleh Partai Perindo, karena memanfaatkan frekuensi publik yang dimilikinya untuk menyiarkan iklan politik. Teguran keras dari Komisi Penyiaran Indonesia yang meminta MNC Group menghentikan tayangan Mars Perindo di media televisi dan radio miliknya. Iklan partai di media milik HT juga diikuti dengan kegiatan partai di tengah masyarakat. Seperti dalam kegiatan bagi-bagi gerobak, partai tidak serta merta memberikan secara cumacuma, melainkan berusaha menjaring dukungan dan ikatan dengan calon pemilih (Susanto, 2013).

Media MNG Group juga menyiarkan figur HT sebagai tokoh utama yang dianggap sebagai personalisasi dari Partai Perindo. Figur HT dalam berbagai iklan politik maupun pemutaran mars partai di MNC Group selalu digambarkan sebagai sosok yang pluralis, peduli dengan permasalahan rakyat, pengusaha sukses, tokoh pemuda, dan seorang nasionalis (Kosasih, 2016; Atmaja, 2017; Haq, 2017). Personalisasi HT yang dianggap lekat dengan Perindo bahkan digambarkan sebagai sosok yang menaruh perhatian besar pada pemberdayaan umat Islam. Media MNC Group rutin menyiarkan aktivitas HT dalam berbagai program partai Perindo di akar rumput. Bahkan, sikap politik HT yang mendukung calon presiden dan wakil presiden tertentu termasuk perubahan dukungannya juga disiarkan melalui media MNC Group. Keterlekatan yang sangat kuat antara MNC Group, HT dan Perindo seolah-olah ingin membangun ingatan pada publik bahwa telah ada wadah "perjuangan politik" dan sosok "alternatif" yang dapat memenuhi kebutuhan rakyat, sehingga diharapkan dapat menggerakkan pemilih untuk memberikan suaranya (Salsabila, 2017).

Hasil dari pemanfaatan media-media milik HT untuk membesarkan partai Perindo dapat dilihat cukup berhasil. Berdasarkan hasil survei yang dikeluarkan oleh Lingkaran Survei Indonesia (LSI) pada 24 Januari 2018 menunjukan Perindo memimpin partai baru dan partai gurem, yakni Perindo, PSI, PKPI, dan PBB. Perindo suara paling tinggi di 3,0, meskipun belum melebihi ambang batas parlemen atau parliamentary threshold sebesar 4 persen di Pemilihan Umum (Pemilu) 2019 (Lazuardi, 2018). 
Gambar 1: Grafik Hasil Survei LSI terhadap Elektabilitas Parpol (Januari 2018)

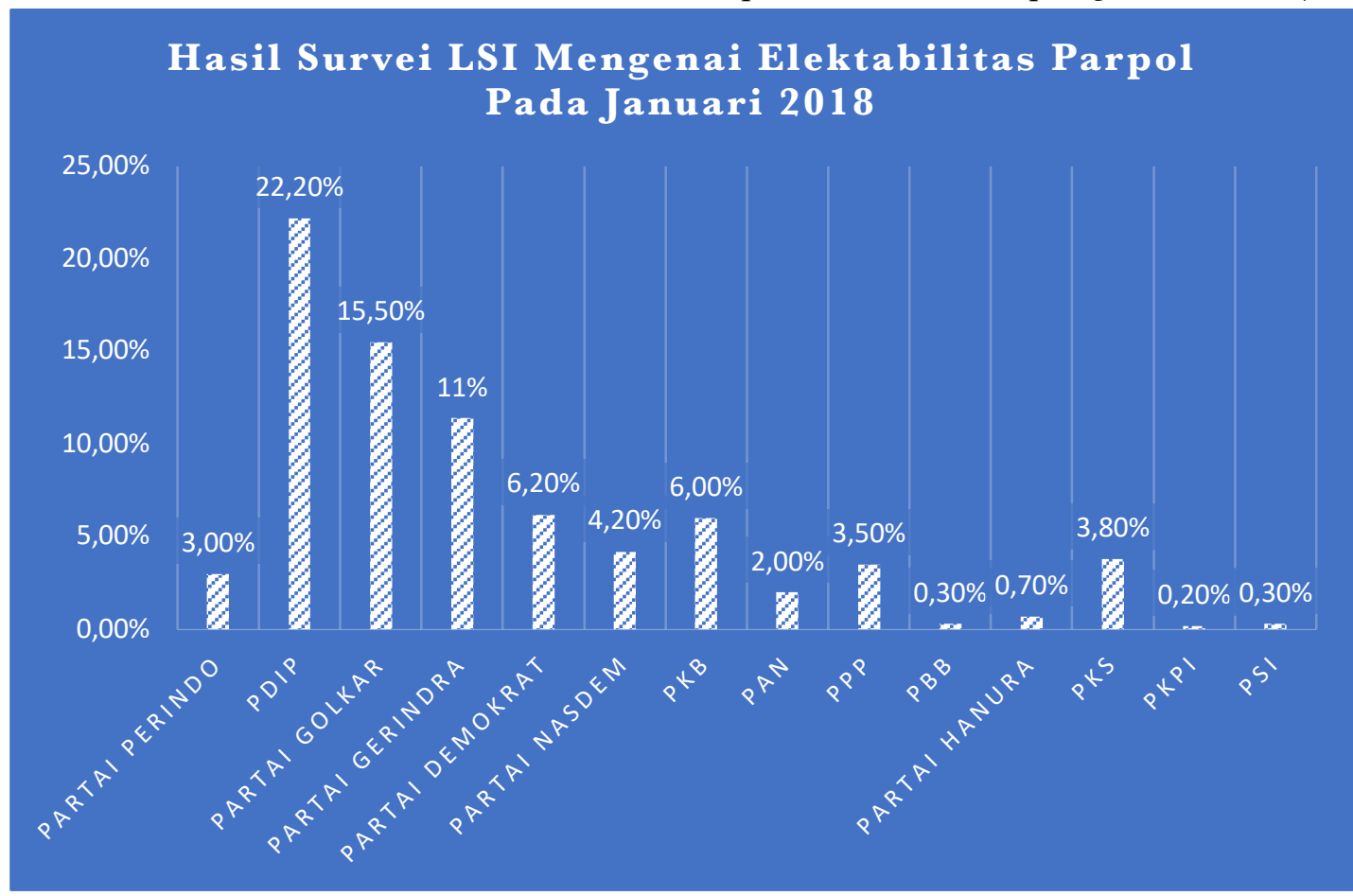

Sumber: Tribunnews.com, 25 Januari 2018

Hasil survei lain dari Alvara Research Center menunjukan temuan yang cukup menarik. Salah satu partai politik (parpol) baru, yakni Partai Persatuan Indonesia (Perindo) memiliki elektabilitas cukup tinggi, bahkan melampaui parpol lama.Tingkat keterpilihan Partai Perindo setara dengan Partai Keadilan Sejahtera (PKS) yakni sebesar 2,6 persen. Angka ini mengalahkan parpol yang jauh lebih dulu eksis, yakni Partai Persatuan Pembangunan (PPP) yang hanya meraup perolehan 1,2 persen. Elektabilitas Partai Perindo juga menengelamkan Partai Hanura (1,6 persen) (Suryowati, 2018).

Menurut pendiri Alvara Research Center, Hasanuddin Ali menyatakan bahwa ada dua faktor yang menyebabkan partai besutan Hary Tanoesoedibjo memiliki elektabilitas cukup tinggi. Pertama, iklan mars Partai Perindo yang begitu masif menghiasi layar kaca menjadi faktor penentu elektabilitas partai yang didirikan tahun 2015 itu terus melejit. Faktor kedua yaitu soliditas Partai Perindo terbilang cukup kuat dibanding parpol peserta pemilu lain (Suryowati, 2018). 
Gambar 2: Grafik Hasil Survei Alvara Research Center terhadap Elektabilitas Parpol (Januari 2018)

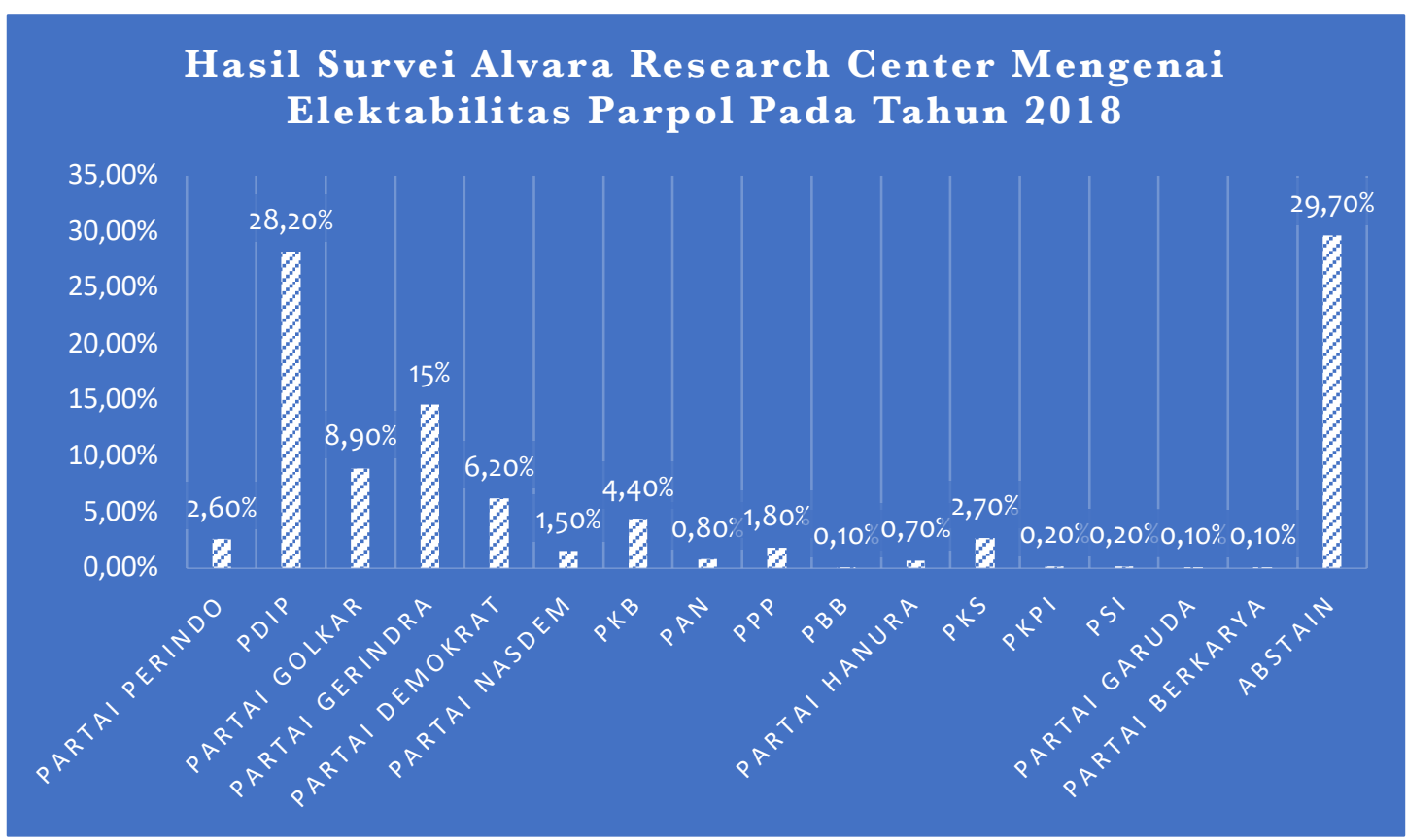

Sumber: Jawapos.com, 28 Februari 2018.

HT dan jajarannya terus berupaya menunjukan keseriusannya untuk membesarkan Perindo baik dalam hal sosialisasi maupun pembiayaan. Dalam hal sosialisasi partai, iklan politik di media terus berusaha ditingkatkan untuk mengenalkan pada publik mengenai adanya Partai Perindo. Data dari Adstensity, sebuah platform yang menghitung dan menganalisa data iklan di televisi mencatatkan selama kurun waktu tiga bulan, terhitung dari November 2015 hingga Januari 2016, iklan partai Perindo di MNG Group mencapai 1918 kali. Rincian iklan tersebut yakni RCTI (648 kali), MNCTV (630 kali) dan Global TV (640 kali). Berdasarkan perhitungan Adstensity, nilainya berkisar Rp 132 milliar. Nilai tersebut tentu saja tergolong mahal untuk sebuah promosi di televisi dalam waktu relatif singkat hanya tiga bulan. Jika menilik dari data-data di atas, Hary Tanoe terlihat serius ingin membesarkan partainya. Secara masif, HT berusaha mengenalkan Perindo ke masyarakat Indonesia hingga diharapkan bisa mendulang suara pada Pemilu 2019 (Hanifan, 2018).

Pembiayaan Perindo juga terbilang lebih siap dibanding partai lain, sehingga ikut mempengaruhi popularitas partai yang terus meningkat. Berdasarkan survei Cyrus Network yang dilakukan pada 27 hingga 3 April 2018 menunjukan bahwa publik menganggap Perindo sebagai partai dengan pembiayaan yang tinggi dibanding partai lain. Survei ini melibatkan 1.239 orang responden dari 123 desa/kelurahan di 34 provinsi. Survei dilakukan dengan wawancara tatap muka. Tingkat keyakinan survei sebesar 95 persen dengan margin of error sebesar 3 persen. Hasilnya, Perindo menempati urutan teratas dalam hal survei kesiapan logistik dengan perolehan 21,2 persen, dianggap 
sebagai partai yang paling banyak uang. Di urutan terbawah, alias partai yang dipersepsikan paling miskin adalah Partai Garuda dengan perolehan sebesar 0,1 persen (Damarjati, 2018).

Gambar 3: Grafik Hasil Survei Persepsi Publik Mengenai Kesiapan Logistik Parpol

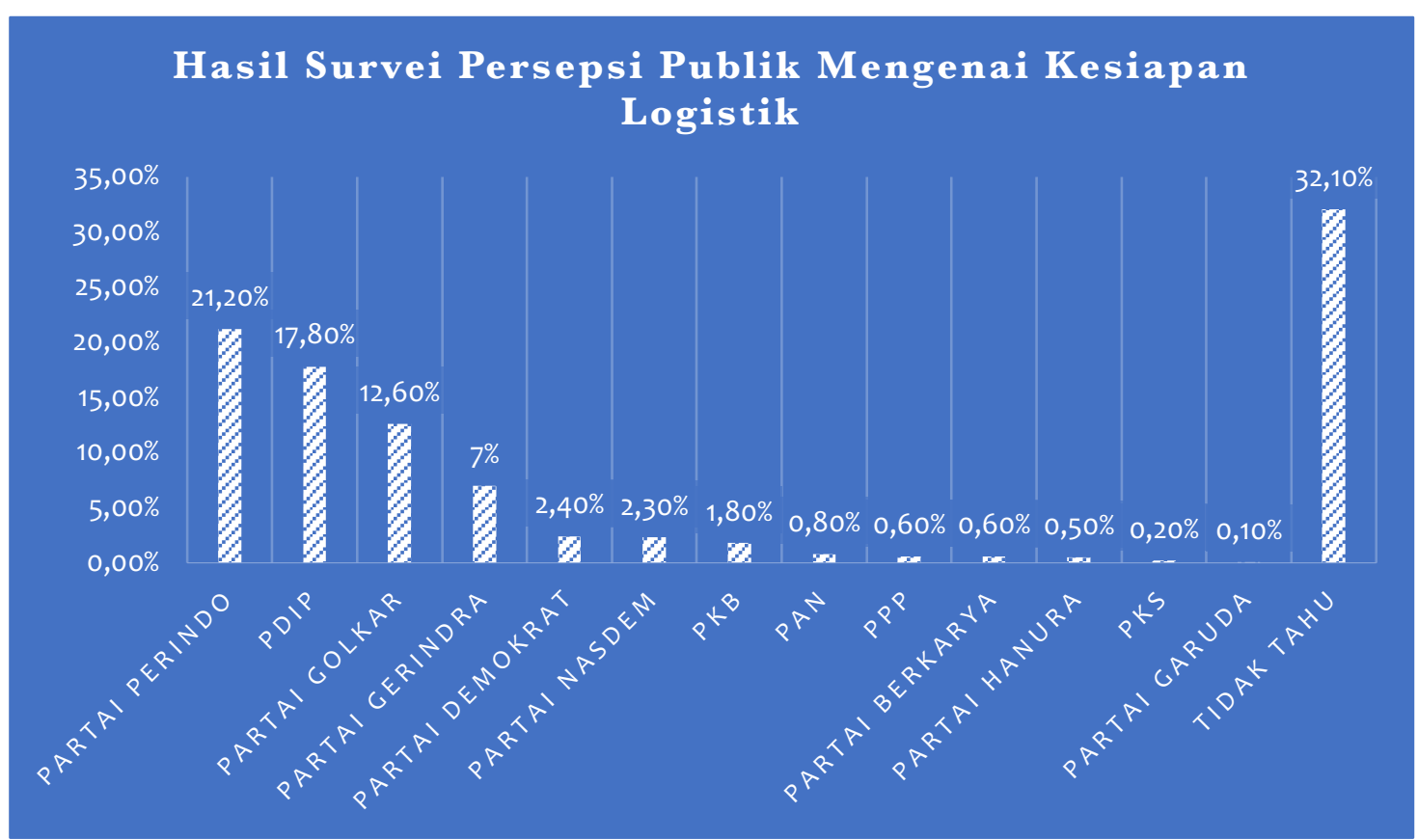

Sumber: News.detik.com, 19 April 2018.

Perindo sempat unggul pada berbagai hasil survei elektabilitas yang dipublikasikan di antara partai baru dan gurem serta sempat diperkirakan akan masuk ke Senayan. Akan tetapi, Perindo kenyataannya tidak dapat lolos pada pemenangan di tingkat nasional, meskipun berbagai pemberian barang pada calon pemilih dan iklan politik di media milik HT dilakukan. Hasil rekapitulasi suara Komisi Pemilihan Umum (KPU) menunjukan bahwa Partai Perindo menduduki peringkat sepuluh dengan raihan 3.738.320 suara atau 2,67 persen (CNNIndonesia.com, 2019). Perindo memang memiliki nilai iklan yang sangat besar, akan tetapi pada masa kampanye terbuka penayangannya tidak lebih banyak dari Partai Solidaritas Indonesia (PSI). Perindo juga sebenarnya sedang menghadapi sanksi dari Komisi Penyiaran Indonesia (KPI) menjelang masa kampanye terbuka, sehingga penayangan iklan di media HT menjadi tidak semasif sebelumnya. Berdasarkan data PT Sigi Kaca Pariwara menunjukan bahwa belanja iklan partai politik di 13 stasiun televisi pada masa kampanye Pileg (Pemilihan Legislatif) 2019 mencapai Rp 602,98 miliar. Partai Solidaritas Indonesia (PSI) menjadi yang paling banyak muncul penayangannya dengan 1.277 iklan senilai Rp 42,84 miliar selama 23 Maret-13 April 2019 sesuai dengan masa kampanye terbuka (Wartaekonomi.co.id, 2019). Aspek iklan politik juga ternyata tidak langsung berpengaruh kepada keterpilihan Perindo disebabkan hanya mampu menggerakkan segelintir pemilih pemula. Rapuhnya figur HT 
dalam kepemimpinan Perindo juga menjadi penyebab gagalnya Perindo di tingkat nasional (Ucu, 2019). Ada setidaknya dua faktor yang dapat menyebabkan strategi klientelistik yang diambil Perindo tidak berhasil mendorong pemilih tergerak untuk memberikan suaranya.

Pertama, Partai Perindo memang sempat menayangkan iklan politik dan mars partai secara masif, tetapi media milik HT mendapat peringatan dari berbagai stakeholder disebabkan dianggap telah mendahului berkampanye di luar waktu tahapan penyelenggaraan pemilu. Peringatan dari pemangku kepentingan ini membuat media HT memutuskan untuk menghentikan penayangan iklan politik Perindo. Akibatnya, pengenalan program partai melalui media milik HT tidak semasif sebelum adanya peringatan. Iklan politik Perindo di media milik HT mendapat peringatan dari Komisi Penyiaran Indonesia (KPI) dan dianggap melanggar regulasi oleh penyelenggara pemilu.

Menurut KPI, durasi iklan ini berkisar lima sampai sepuluh kali tayang pada tiap harinya. Iklan ini menuai kontroversi dan dianggap meresahkan, khususnya bagi para orang tua. Mereka mengeluhkan bahwa anak-anaknya lebih hafal mars Partai Perindo dari pada lagu-lagu kebangsaan lainnya. Akibat penayangan iklan ini secara terus menerus dan secara tidak langsung membuat partai tersebut telah melakukan kampanye politik. Partai Perindo dianggap melakukan kampanye di luar jadwal kampanye yang telah ditentukan oleh lembaga pemilihan umum, KPU. Berdasarkan penemuan ini, pihak KPI memberikan surat edaran ke semua lembaga penyiaran untuk tidak melakukan kampanye dalam bentuk apapun di luar masa kampanye. Akhirnya, KPI menjatuhkan sanksi kepada MNC Group. Pelanggaran yang dijatuhkan KPI disebabkan menilai MNG Group menayangkan iklan ini untuk kepentingan kelompok (Partai Perindo) bukan untuk kepentingan publik.

Rapat antara Badan Pengawas Pemilu (Bawaslu) dengan Kepolisian RI dan Kejaksaan Agung menyimpulkan bahwa iklan Partai Perindo di stasiun televisi memenuhi unsur kampanye dini. Namun, Partai Perindo tidak diberi sanksi lantaran kendala syarat formal di Sentra Gakkumdu (Penegakan Hukum Terpadu). Materi iklan Perindo memenuhi unsur iklan kampanye melalui media elektronik yang dilakukan diluar jadwal kampanye. Proses penindakan yang seharusnya dikukan melalui Sentra Gakkumdu kenyataannya tidak terlaksana disebabkan belum terbentuknya sekretariat bersama saat proses pembahasan dugaan pelanggaran iklan politik Perindo (Hamdi, 2018).

Syarat formal sebagaimana diatur dalam Pasal 486 UU No.7/2017 yang mengatur mengenai pembentukan Sentra Penegakan Hukum Terpadu belum terpenuhi. Amanat pembentukan Sentral Gakkumdu meliputi aturan mengenai fungsi penyidikan dan penuntutan yang terdapat di institusi Kepolisian dan Kejaksaan. Selain itu, selama proses pembahasan terkait kasus penayangan iklan Perindosampai ternyata Peraturan Komisi Pemilihan Umum (PKPU) belum merinci pengertian kampanye dan bedanya 
dengan citra diri. Perindo tetap bersikukuh bahwa penayangan iklan politik di media milik HT dianggap sebagai bagian dari sosialisasi partainya yang baru (Sicca, 2018).

Kedua, strategi HT untuk menggerakkan Perindo dengan jaringan patronasenya ternyata tidak lantas menyebabkan kader-kader di kantor cabang mengikuti arahan partai dalam upaya memenangkan pemilihan. Banyak calon anggota legislatif yang diusung oleh Perindo dan beberapa kantor cabang enggan untuk melengkapi laporan awal dana kampanye kepada KPU sebagai syarat untuk mengikuti pemilu. Akibatnya, calon anggota legislatif dan beberapa kantor cabang partai Perindo dicoret keikutsertaannya oleh KPU untuk mengikuti pemilu. Pembatalan oleh KPU dilakukan, karena parpol tidak menyampaikan Laporan Dana Awal Kampanye (LADK) sesuai dengan jadwal yang diatur dalam Undang-Undang Nomor 7 Tahun 2017 tentang Pemilu.

Perindo dibatalkan keikutsertaannya dalam pemilu di 2 kabupaten dan 2 kota yang tersebar di empat provinsi (Paat, 2019). Caleg dari Partai Persatuan Indonesia (Perindo) merupakan yang paling banyak tidak melaporkan LPPDK (Laporan Penerimaan dan Pengeluaran Dana Kampanye) kepada KPU, yakni 222 orang (Bayu, 2019). Perindo menjadi tidak efektif dalam menggerakkan infrastruktur politiknya terutama untuk mendukung pemenangan di tingkat pusat. Strategi klientelistik yang gencar dilakukan oleh Perindo melalui bantuan UMKM maupun berbagai "program insidental" pun tidak dapat dilaksanakan secara maksimal disebabkan kader partai sebagai pengganti broker tidak bekerja secara maksimal.

Ketiga, meskipun HT memanfaatkan jaringan patronase yang dimilikinya untuk menggerakkan Perindo kenyataannya kesolidan kader di kantor pusat dan kantor cabang berbeda drastis. Arahan dari HT dan kantor pusat Perindo yang terkesan top down menyebabkan kurang diperhatikannya aspirasi kader di kantor cabang. Kantor pusat Perindo yang diisi orang-orang dekat HT kurang responsif dalam menyerap aspirasi dari berbagai kantor cabang partai. Akibatnya, banyak pengurus kantor cabang yang mengundurkan diri, diberhentikan serta banyak kader pula yang menghentikan aktivitasnya secara keseluruhan sebagai bentuk luapan kekecewaan menjelang masa kampanye terbuka pemilu legislatif. Perindo menjadi semakin kesulitan untuk menggerakkan infrastruktur partai dalam rangka memobilisasi pemilih untuk memberikan suaranya pada masa pungutan suara.

Di Jawa Barat, Ade Wardhana Adinata mengundurkan diri sebagai Ketua Dewan Pimpinan Wilayah (DPW) Partai Persatuan Indonesia Jawa Barat pada 22 Februari 2018 (Halim, 2018). Ade Wardhana Adinata mundur dari kepengurusan partai disebabkan ingin fokus pada pencalonan dirinya secara perseorangan sebagai calon bupati Bogor pada Pilkada Serentak tahun 2018. Ade Wardhana Adinata beralasan bahwa partai banyak menuntut dirinya untuk memberikan lebih banyak waktu pada upaya Pileg dan Pilpres tahun 2019 (Radarbogor.id, 2018). Pengurus DPW Perindo Jawa Barat lain yakni, Nace Permana bersama beberapa kader lain juga memilih berpindah ke Partai Gerinda 
disebabkan mengakui bahwa memiliki perbedaan pandangan dengan kantor pusat dalam pengelola (Jabarekspres.com, 2018).

Selain itu, 900 kader dan pengurus inti DPD (Dewan Pimpinan Daerah) Kota Bogor menyatakan keluar dari Partai Perindo. Mantan Ketua DPD Perindo Kota Bogor menyatakan bahwa perbedaan cara pandang pengelolaan dan manajemen internal yang tidak searah dan sejalan menjadi alasan dirinya dan banyak kader memilih keluar (Wahyudi, 2016). Kader DPD Perindo Kota Bogor merasa visi-misi Perindo untuk memajukan UMK dan perekonomian di Kota Bogor tidak terlaksana. Kader dan pengurus DPD yang mayoritas memiliki latar belakang praktisi dan pengusaha menganggap platform partai tidak benar-benar dilaksanakan. Kader DPD Kota Bogor merasa konsentrasi Partai Perindo lebih dominan kepada politik praktis daripada pelaksanaan visi-misi untuk peningkatan kesejahteraan masyarakat dengan potensi Usaha Mikro Kecil dan Menengah. Padahal, pengurus dan kader Partai Persatuan Indonesia (Perindo) Kota Bogor belum lama terbentuk (Pesisirnews, 2016).

Di Jawa Tengah, Perindo juga menghadapi kemelut di antara para kader dan pengurus di tingkat DPD. Di Sukoharjo, Zaenal Mustofa selaku Ketua DPD secara resmi telah menyatakan pengunduran dirinya dari Perindo pada 1 Juni 2018. Surat pengunduran diri Zeanal sudah disampaikan sebanyak tiga kali, baik melalui lisan, rapat partai maupun tertulis (Bramantyo, 2018). Mantan Ketua DPD Perindo Sukoharjo memutuskan mundur dari Perindo dan memilih bergabung ke Partai Persatuan Pembangunan (PPP) (Mukti, 2018). DPD Perindo Karanganyar juga harus menghadapi konflik internal di antara para kadernya. 17 Dewan Pimpinan Cabang (DPG) serta calon kegislatif menolak menghadiri peresmian kantor baru DPD Partai Perindo. Konflik Perindo di Karanganyar disebabkan mayoritas DPG menolak pengangkatan baru Ketua DPD baru yang tidak sesuai dengan usulan para kader kepada pihak DPW (Burhani, 2018).

Di DPW Perindo Yogyakarta, Bacaleg dan pengurus organisasi sayap Pemuda Perindo di Yogyakarta mengundurkan diri (Jogja.Tribunnews.com, 2018). Ada 45 organisasi Pemuda Perindo dan bakal caleg sebanyak 8 orang yang menyatakan mundur dari keanggotaan DPW Yogyakarta. Mereka menilai Partai Perindo maupun organisasi sayap seperti jalan di tempat. Alasan lain adalah pengelolaan dana partai yang dinilai tidak transparan. Ada juga faktor tekanan agar para bacaleg tidak mendukung Presiden Joko Widodo di Pilpres 2019 yang dianggap tidak sesuai dengan arahan Hary Tanoesoedibjo, pendiri sekaligus pucuk pimpinan Perindo (Andayani, 2018).

DPD di jajaran DPW Perindo Jawa Timur harus menghadapi berbagai konflik yang lebih rumit. Partai Perindo Kota Batu ditinggalkan kadernya disebabkan berbeda pandangan dengan pemimpin DPD (Surabayapost.id, 2018). DPD lain di Jombang menghadapi konflik internal disebabkan mayoritas kader tidak setuju dengan pengangkatan kepengurusan baru. Konflik di tubuh DPD Partai Perindo Kabupaten Jombang bermula dari dicopotnya Sekretaris DPD Partai Perindo yakni, Medan 
Amrullah, melalui Surat Keputusan Dewan Pimpinan Pusat Partai Perindo Nomor: 2215 - SK/DPP-PARTAI PERINDO/VI/2018 yang ditetapkan pada tanggal 21 Juni 2018 (Tulungagungtimes.com, 2018). DPD Banyuwangi juga menghadapi masalah mundurnya beberapa kader di tingkat DPC. Sejumlah kader Perindo menyatakan mosi tidak percaya dalam rapat pleno yang dihadiri 11 Dewan Pimpinan Cabang. Mosi tidak percaya ditujukan kepada Ketua Partai Perindo DPD Banyuwangi. Alasan mosi tidak percaya muncul disebabkan Pimpinan DPD Banyuwangi kurang transparan dalam memberikan informasi (Agtvnews.com, 2017).

Di Nganjuk, puluhan kader Partai Perindo Kabupaten Nganjuk ramai-ramai mengundurkan diri dari keanggotaan partai pada Sabtu 14 Juli 2018, atau 3 hari menjelang penutupan pendaftaran bacaleg di KPU Nganjuk (Analisapublik.com, 2018). Bahkan, ada beberapa anggota partai terpaksa mencabut sebagai bakal calon legislatif di tingkat Kabupaten Nganjuk pada periode pemilu 2019. Mundurnya sejumlah kader partai disebabkan oleh kegelisahan dan kekecewaan sejumlah anggota terhadap kepemimpinan DPD Partai Nganjuk (Matakamera.net, 2018). DPD Perindo Kediri juga menghadapi masalah muncul mundurnya kader dari daerah Kayenkidul, Gampengrejo, Ngasem dan beberapa wilayah lain. Terdapat 21 pengurus di tingkat kecamatan yang memilih untuk mundur disebabkan adanya konflik internal di tubuh DPD Perindo Kabupaten Kediri. Konflik internal Perindo Kabupaten Kediri terjadi disebabkan kurang terbukanya elit partai di DPD dalam kepengurusan (Faktanews.co.id, 2018). Di daerah lain baik di tingkat DPW maupun DPD, Perindo juga menghadapi berbagai konflik internal yang menyebabkan tidak maksimalnya mesin partai untuk menjalankan berbagai startegi untuk memenangkan pemilu, khususnya di tingkat pusat.

\section{Penutup}

Keterlekatan antara MNC Group dan Partai Perindo yang dipimpin Hary Tanoe menunjukan adanya upaya menggunakan personalisasi politik untuk membangun hubungan dengan calon pemilih. Hary Tanoe mengerahkan sumber daya yang dimilikinya di MNC Group untuk menggerakkan Perindo dengan memasukkan orangorang dekatnya di kantor pusat partai, menggunakan medianya untuk mempromosikan program, dan memberikan arahan top down kepada kantor cabang. HT juga menggunakan personalisasi politiknya untuk menggerakkan mesin politik Perindo dengan memberikan berbagai barang maupun pelayanan kepada calon pemilihnya agar terjalin hubungan yang baik dan berdampak pada terpilihnya partai/kandidat saat pemungutan suara. Berbagai pemberian yang dilakukan Perindo atas arahan HT pada dasarnya telah mengikat calon pemilih dibuktikan dengan adanya konsekuensi yang disepakati serta adanya pemantauan dari kader Perindo. 


\section{Ucapan Terima Kasih}

Artikel ini merupakan pengembangan dari naskah penulis dalam Seminar "Media, Pemilu, dan Komunikasi Politik: Menyambut Tahun Politik Indonesia 2018-2019” yang dilaksanakan pada 13 Juli 2018 oleh Magister Ilmu Politik dan Magister Ilmu Komunikasi, Fakultas Ilmu Sosial dan Ilmu Politik, Universitas Diponegoro.

\section{Pendanaan}

Penulis tidak menerima bantuan pembiayaan untuk penelitian, kepenulisan (authorship), dan publikasi dari pihak manapun

\section{Daftar Pustaka}

Agtvnews.com. (2017) Pengurus Partai Perindo Dikabarkan Mundur Massal, agtonews.com. Available at: https://agtvnews.com/2017/10/pengurus-partai-perindodikabarkan-mundur-massal.html.

Alfani, H. (2014) 'Perspektif Kritis Ekonomi Politik Media Konglomerasi, Regulasi Dan Ideologi', Avant Garde: Jurnal Ilmu Komunikasi, 2(2), pp. 10-26.

Analisapublik.com. (2018) Jadi Perbincangan Paling HOT, Sejumlah Kader Perindo Mundur dan Gabung Ke Hanura, analisapublik.com. Available at: http://analisapublik.com/ 2018/07/15/jadi-perbincangan-paling-hot-sejumlah-kader-perindo-mundur-dangabung-ke-hanura/ (Accessed: 10 July 2019).

Andarwati (2018) Hubungan Antara Menonton Iklan Partai Perindo Di Televisi Dan Popularitas Partai Perindo Di Kalangan Mahasiswa UNHAS. Universitas Hasanuddin.

Andayani, D. (2018). Kader di DIY 'Bedol Desa' Mundur, Perindo: Kita Persilakan, Detik.com. Available at: https://news.detik.com/berita/4106340/kader-di-diy-bedol-desamundur-perindo-kita-persilakan/ (Accessed: 10 July 2019).

CNNIndonesia.com. (2019) Hasil Pahit Bakar Duit Kampanye Perindo di Televisi, CNN Indonesia. Available at: https://www.cnnindonesia.com/nasional/ 20190521 140658-32-396883/hasil-pahit-bakar-duit-kampanye-perindo-di-televisi (Accessed: 10 July 2019).

Ardiyan, D. and Sulandjari, R. (2017) 'Korelasi Iklan Politik Partai Perindo Di Media Mnc Terhadap Persepsi Tentang Pencitraan Politik Pada Masyarakat Dusun Jangglengan Kecamatan Bandungan', Egaliter, 1(1), pp. 1-14.

Ariviyanti, B. C. and Nurfebiaraning, S. (2017) 'Analisis Aktivitas Pembetukan Citra Politik Hary Tanoesoedibjo Studi Semiotika Peirce pada Iklan TV Perindo "Mars Perindo Versi 2"", Channel, 5(1), pp. 48-58.

Atmaja, B. R. W. (2017) Kepemimpinan Hary Tanoesoedibjo dalam Partai Perindo Perspektif Profetik. Universitas Islam Negeri Sunan Kalijaga.

Bahruddin, M. (2014) 'Tantangan Regulasi Penyiaran: Pencitraan Politik Di Era Konvergensi Media', in Comicos, pp. 203-209.

Bayu, D. J. (2019) 554 Caleg Tak Serahkan Laporan Dana Kampanye, Perindo Terbanyak, katadata.co.id. Available at: https://katadata.co.id/berita/2019/05/03/554caleg554-caleg-dpr-tak-serahkan-laporan-akhir-dana-kampanye-ke-kpu (Accessed: 10 July 2019).

Bramantyo (2018) Ketua DPD Sukoharjo Mundur, Perindo Fateng Gelar Konsolidasi, Okezone.com. Available at: https://news.okezone.com/read/2018/05/28/512/1903466/ketuadpd-sukoharjo-mundur-perindo-jateng-gelar-konsolidasi (Accessed: 10 July 2019).

Burhani, D. T. (2018) Cairkan Komunikasi Terputus di Perindo Karanganyar, Hary Tanoe Tunjuk Ketua Baru, rmoljateng.com. Available at: http://www.rmoljateng.com/read/2018/ 
11/04/13583/Cairkan-Komunikasi-Terputus-di-Perindo-Karanganyar,-Hary-

Tanoe-Tunjuk-Ketua-Baru- (Accessed: 10 July 2019).

Calvo, E. and Murillo, M. V. (2013) 'When Parties Meet Voters: Assessing Political Linkages through Partisan Networks and Distributive Expectations in Argentina and Chile', Comparative Political Studies.

Damarjati, D. (2018) Perindo Dianggap Partai Terkaya, Partai Garuda Termiskin, Detik.com. Available at: https://news.detik.com/berita/3980563/perindo-dianggap-partai\%0Aterkaya-partai-garuda-termiskin (Accessed: 17 June 2018).

Detik.com. (2012) Hilangnya Dinasti Soeharto di Global Mediacom, Detik.com. Available at: https://finance.detik.com/bursa-dan-valas/d-1908155/hilangnya-\%0Adinastisoeharto-di-global- mediacom (Accessed: 18 June 2018).

Dwita, D. (2016) 'Televisi Dan Kepentingan Pemilik Modal Dalam Perspektif Teori Ekonomi Politik Media', Furnal Ipteks Terapan, 8(4), pp. 252-261.

Faktanews.co.id. (2018) Sejumlah DPC Partai Perindo Nyatakan Mosi Tak Percaya, faktanews.co.id. Available at: http://faktanews.co.id/sejumlah-dpc-partai-perindonyatakan-mosi-tak-percaya/ (Accessed: 10 July 2019).

Fernando, A. (2012) Mencermati Manuver Hary Tanoe, inilah.com. Available at: https://m.inilah.com/news/detail/1877229/mencermati- manuver-hary- tanoe (Accessed: 25 June 2018).

Gherghina, S. and Volintiru, C. (2017) 'A New Model Of Clientelism: Political Parties, Public Resources, And Private Contributors', European Political Science Review, 9(1), pp. 115-137.

Giovanni (2016) Representasi Islam pada Iklan-Iklan Partai Perindo di Televisi. Universitas Islam Negeri Syarif Hidayatullah.

Habsari, S. U. H. (2012) 'Spasialisasi Kelompok Media MNG', Furnal Unpand, pp. 1-17.

Halim, H. A. (2018) Ingin Independen, Ade Wardhana Keluar Dari Perindo, pikiranrakyat.com. Available at: https://www.pikiran-rakyat.com/jawa-barat/2018/02/22/inginindependen-ade-wardhana-keluar-dari-perindo-419989 (Accessed: 10 July 2019).

Hallin, D. C. and Papathanassopoulos, S. (2000) Political Clientelism and the Media: Southern Europe and Latin America in Comparative Perspective. Available at: www. portalcomunicacion.com/both/opc/client.pdf (Accessed: 13 June 2018).

Hamdi, I. (2018) Bawaslu Gelar Pleno Putuskan Dugaan Pelanggaran Iklan Perindo, tempo.co. Available at: https://nasional.tempo.co/read/1072181/bawaslu-gelar-plenoputuskan-dugaan-pelanggaran-iklan-perindo (Accessed: 10 July 2019).

Hanifan, A. F. (2018) Menancapkan Mars Perindo lewat Stasiun TV milik Pribadi, tirto.id. Available at: https://tirto.id/menancapkan- mars-perindo- lewat-stasiun-tv- milikpribadi-nn (Accessed: 18 June 2018).

Haq, A. A. (2017) Representasi Makna Pesan Hary Tanoesoedibjo Pada Iklan Mars Partai Perindo Di Televisi (Kajian Semiotika). Universitas Hasanuddin.

Hariyadi, T. (2018) 'Runtuhnya Pilar Demokrasi, Politik Kuasa Media Partai Perindo Di MNC Grup', in DiMCC Conference Proceeding, pp. 110-130.

Hasan, K. (2014) 'Kajian Netralitas Industri Media Massa dalam Pileg 2014', furnal SUWA Universitas Malikussaleh, 12(1), pp. 1-18.

Hastomo, A. D. and Aras, M. (2017) 'Analisis Strategi Komunikasi Pemasaran Politik Hary Tanoesoedibjo (Studi Kasus Program UMKM sebagai Political Branding Partai Persatuan Indonesia (Perindo)', Prosiding Konferensi Nasional Komunikasi, 1(1), pp. 87-99.

Jabarekspres.com. (2018) Berbeda Pandangan, Nace Pindah ke Gerindra, jabarekspres.com. 
Available at: http://jabarekspres.com/2018/berbeda-pandangan-nace-pindah-kegerindra/ (Accessed: 10 July 2019).

Jati, W. R. (2013) 'Politik Persuasif Media: Peran Media Dalam Pemilu Presiden Indonesia 2001-2009', Jurnal Penelitian Politik, 10(3), pp. 15-30.

Jogja.Tribunnews.com. (2018) Dilarang Dukung fokowi, Seluruh Pengurus Pemuda Perindo di DIY Mengundurkan Diri, jogja.tribunnewes.com. Available at: https://jogja.tribunnews.com/ 2018/07/09/dilarang-dukung-jokowi-seluruh-pengurus-pemuda-perindo-di-diymengundurkan-diri (Accessed: 10 July 2019).

Khumairoh, N. S. and Aida, N. (2018) 'Analisa Efektifitas Iklan Televisi Partai Perindo Model Epic (Iklan Dengan Aktor Utama Ketua Umum Partai Perindo)', Pamator, 11(2), pp. 1-7.

Kitschelt, H. (2000) 'Linkages between Citizens and Politicians in Democratic Polities', Comparative Political Studies, 33(6/7), pp. 845-879.

Kitschelt, H. (2011) 'Clientelistic Linkage Strategies, A Descriptive Exploration', in Workshop on Democratic Accountability Strategies. Duke University.

Kitschelt, H. (2015) 'Social Policy, Democratic Linkages, and Political Governance', in The Quality of Government and the Performance of Democracies, Gothenburg.

Kosasih, R. A. A. (2016) Analisa Semiotik Citra Politik Hary Tanoesoedibjo dalam Iklan Partai Perindo di Televisi. Universitas Islam Negeri Syarif Hidayatullah.

Kresna, M. (2018) Perindo, Partai Politik Rasa MNG, tirto.id. Available at: https://tirto.id/perindo-partai-politik-rasa-mnc-cNvZ (Accessed: 10 July 2019).

Lazuardi, G. (2018) Didukung Media Massa, Elektabilitas Partai Perindo Ungguli PAN dan Hanura, tribunnews.com. Available at: http://www.tribunnews.com/nasional/2018/ 01/25/didukung-media- massa-elektabilitas-partai-perindo-ungguli-pan-danhanura (Accessed: 18 June 2018).

Manado.tribunnews.com (2018) Sejarah Partai Perindo dan Penantiannya di Pemilu 2019, manado.tribunnews.com. Available at: http://manado.tribunnews.com/2018/02/22/ sejarah-partai-perindo-dan- penantiannya-di-pemilu-2019?page $=1$ (Accessed: 16 June 2018).

Mancini, P. (2011) Between Commodifcation and Lifestyle Politics Does Silvio Berlusconi provide a New Model of Politics for the Twenty-First Century? Oxford: Reuters Institute for the Study of Journalism, Department of Politics and International Relations, University of Oxford.

Matakamera.net. (2018) Kader Perindo Nganjuk Ramai-Ramai Mundur, Langsung Gabung Hanura, matakamera.net. Available at: http://www.matakamera.net/2018/07/kaderperindo-nganjuk-ramai-ramai.html (Accessed: 10 July 2019).

Mukti, A. H. (2018) Mundur dari Ketua DPD Perindo Sukoharjo, Zaenal Mustofa Pindah ke PPP, jateng.tribunnews.com. Available at: https://jateng.tribunnews.com/2018/05/23/ mundur-dari-ketua-dpd-perindo-sukoharjo-zaenal-mustofa-pindah-ke-ppp (Accessed: 10 July 2019).

Noor, R. M. (2017) Pengaruh Terpaan Iklan Partai Perindo Dan Berita Seputar Partai Perindo Di Televisi Terhadap Persepsi Pemilih Pemula Mengenai Partai Perindo, e-journal Undip. Available at: https://ejournal.undip.ac.id/index.php/interaksi/article/view/ 19477/13514 (Accessed: 10 July 2019).

Ochtiva, B. (2017) Opini Pemilih Pemula Surabaya Terhadap Citra Yang Ditampilkan Pada Iklan Politik Mars Partai Perindo. Available at: http://repository.unair.ac.id/67887/3/ Sec.pdf (Accessed: 15 June 2018).

Paat, Y. (2019) KPU Batalkan Kepesertaan Pemilu 11 Parpol di Sejumlah Daerah, beritasatu.com. 
Available at: https://www.beritasatu.com/politik/544308/kpu-batalkankepesertaan-pemilu-11-parpol-di-sejumlah-daerah (Accessed: 10 July 2019).

Paolucci, C. (2006) 'A firm masquerading as a party transforms Italy: Berlusconi's Forza Italia', in European Consortium of Political Research, Joint Sessions, Intercollege Nicosia, Cyprus, pp. 1-20.

Pembayun, J. G. (2015) 'Konglomerasi Media dan Dampaknya pada Pilpres 2014', Interaksi, 4(2), pp. 109-116.

Pesisirnews. (2016) Oalah Pengurus Partai Perindo Kota Bogor Mundur Secara Masal, pesisimews.com. Available at: https://pesisirnews.com/Politik/Oalah-PengurusPartai-Perindo-Kota-Bogor-Mundur-Secara-Masal (Accessed: 10 July 2019).

Radarbogor.id. (2018) Ade Wardhana Mundur dari Perindo, radarbogor.id. Available at: http://www.radarbogor.id/2018/02/23/ade-wardhana-mundur-dari-perindo/ (Accessed: 10 July 2019).

Rahmah, M. and Maimun (2018) 'Strategi Marketing Partai Persatuan Indonesia (Perindo) Dalam Meghadapi Pemilu Tahun 2019 (Studi kasus di Provinsi Aceh)', Furnal Ilmiah Mahasiswa FISIP Unsyiah, 3(3), pp. 1-14.

Rahman, F. A. et al. (2018) 'Bias Politik Dibalik Sebuah Media: Relevansi Sosialisasi Politik Di Indonesia', Sosietas, 8(2), pp. 553-561.

Rohman, A. Z. F. and Afala, L. M. (2017) 'Perindo: The Emergence of The Business Party in Indonesia', in Unhas International Conference on Social and Political Science (UICoSP 2017), pp. 1-5.

Rosalia, L. (2014) 'Konglomerat Media Sebagai Elite Politik: Wacana Dalam Pemberitaan Hary Tanoesodibjo Di Koran Sindo', JURNAL E-KOMUNIKASI, 2(1), pp. 1-14.

Salsabila, A. (2017) Representasi Citra Politik Harry Tanoesoedibjo Dalam Video Klip Mars Partai Perindo. Universitas Islam Negeri Sunan Kalijaga.

Setiawan, Y. B. (2010) 'Tekanan Konglomerat Media terhadap Otonomi Individual Para Praktisi (Kasus Keberpihakan pada Kandidat Melalui Pemberitaan Tv One, Antv dan Metro Tv, Selama Masa Pencalonan Ketua Umum Partai Golkar 2009-2014)', The Messenger, 2(1), pp. 49-50.

Sicca, S. P. (2018) Perindo Tidak Dikenai Sanksi Meski Kampanye di Luar Fadwal, tirto.id. Available at: https://tirto.id/perindo-tidak-dikenai-sanksi-meski-kampanye-diluar-jadwal-cGDh (Accessed: 10 July 2019).

Sitanggang, H. B. N. and Dharmawan, A. (2016) 'Strategi Marketing Hary Tanoesoedibjo Dalam Usaha Membangun Personal Branding Politik', Jurnal Penelitian Pers dan Komunikasi Pembangunan, 20(1), pp. 49-62.

Sucahya, M. (2013) 'Ruang Publik Dan Ekonomi Politik Media', Jurnal Komunikasi, 2(2), pp. 15-22.

Surabayapost.id. (2018) Tak Sejalan, Perindo Ditinggal Kadernya, surabayapost.id. Available at: https://surabayapost.id/tak-sejalan-perindo-ditinggal-kadernya/ (Accessed: 10 July 2019).

Suryowati, E. (2018) Iklannya Sering Hiasi TV, Elektabilitas Perindo Kalahkan Partai Lama, jawapos.com. Available at: https://www.jawapos.com/nasional/politik/23/ 02/2018/iklannya-\%0Asering-hiasi-tv-elektabilitas-perindo-kalahkan-partai- lama (Accessed: 18 June 2018).

Susanto, E. H. (2013) 'Media Massa, Pemerintah dan Pemilik Modal', Furnal Komunikasi, 6(1), pp. 477-484.

Sylvany, A. (2018) Pola Rekrutmen Anggota, Pengurus dan Calon Legislatif Partai Perindo Kota 
Surabaya dalam Studi Pluralisme Politik, repository unair. Available at: http://repository.unair.ac.id/74863/ (Accessed: 10 July 2019).

Szwarcberg, M. (2013) 'Building a Following: Local Candidates' Political Careers and Clientelism in Argentine Municipalities', American Politics and Society, 55(3), pp. 1-18.

Tulungagungtimes.com. (2018) Diniali Langgar AD/ART Partai, Ketua DPD Partai Perindo Jombang Disomasi, tulungagungtimes.com. Available at: https://www. tulungagungtimes.com/baca/175683/20180718/151847/diniali-langgar-adartpartai-ketua-dpd-partai-perindo-jombang-disomasi/ (Accessed: 10 July 2019).

Ucu, K. R. (2019) Benarkah PSI dan Perindo Kalah karena Ketumnya Non-Muslim?, republika.co.id. Available at: https://www.republika.co.id/berita/kolom/wacana/19/04/25/ pqiciv282-benarkah-psi-dan-perindo-kalah-karena-ketumnya-nonmuslim (Accessed: 10 July 2019).

Valerisha, A. (2016) 'Dampak Praktik Konglomerasi Media Terhadap Pencapaian Konsolidasi Demokrasi di Indonesia', Furnal Ilmiah Hubungan Internasional, 12(1), pp. $1-17$.

Wahono, T. (2013) Hary Tanoe Bantah Kekayaannya Warisan Keluarga Cendana, Kompas.com. Available at: https://nasional.kompas.com/read/2013/03/10/18500131/readbrandzview.html (Accessed: 18 June 2018).

Wahyudi, D. (2016) 900 Pengurus dan Kader DPD Perindo Kota Bogor Nyatakan Keluar dari Partai, bogor.beritasatu.id. Available at: https://bogor.pojoksatu.id/baca/900-pengurusdan-kader-dpd-perindo-kota-bogor-nyatakan-keluar-dari-partai (Accessed: 10 July 2019).

Walle, N. Van de (2007) 'The Path from Neopatrimonial is m: Democracy and Clientelism in Africa Today', in Working Paper Series No 3-07, Mario Einaudi Center for International Studies.

Wartaekonomi.co.id. (2019) Bukan, Bukan Perindo, Partai Ini Paling Sering Muncul di TV, wartaekonomi.co.id. Available at: https://www.wartaekonomi.co.id/read224188/ bukan-bukan-perindo-partai-ini-paling-sering-muncul-di-tv.html (Accessed: 10 July 2019).

Winters, J. A. (2011) Oligarki. Jakarta: PT Gramedia Pustaka Utama.

Yulianti, T. (2017) Komodifikasi Media Cetak Analisis Ekonomi Politik pada Media Indonesia. Universitas Islam Negeri Syarif Hidayatullah.

Zeke, E. (2014) 'Figur Hary Tanoesoedibjo Di Iklan Media Massa Dalam Persepsi Pemilih Pemula Mahasiswa Fispol UNSRAT', Acta Diurna, 3(1), pp. 1-12.

\section{Tentang Penulis}

Anggalih Bayu Muh. Kamim adalah mahasiswa Departemen Politik dan Pemerintahan, Fisipol, Universitas Gadjah Mada, memiliki minat kajian pada studi pemerintahan, kebijakan publik, politik lokal dan ekonomi politik.

Muhammad Fahmi Sabri adalah mahasiswa Departemen Politik dan Pemerintahan, Fisipol, Universitas Gadjah Mada, memiliki minat pada studi politik dan pemerintahan. 